\title{
Effect of Seasons and Plant Spacings on Yield and Quality Parameters of Various Groundnut (Arachis hypogaea L.) Genotypes
}

\author{
Dhanashri Gawas $^{1 *}$, A. V. Mane ${ }^{1}$, TejasKanase ${ }^{2}$, M. M. Burondkar ${ }^{1}$ and M. C. Kasture ${ }^{3}$ \\ ${ }^{1}$ Department of Agriculture Botany, ${ }^{3}$ Department of SSAC, Dr. BSKKV, Dapoli, \\ Maharashtra, India \\ ${ }^{2}$ Department of Plant Physiology, IGKV, Raipur, Chhattisgarh, India \\ *Corresponding author
}

\section{A B S T R A C T}

Keywords

Arachishypogaea,

Plant spacing,

Quality, Genotypes

Article Info

Accepted:

20 September 2020

Available Online:

10 October 2020
The study was conducted at the Education and Research Farm of the Department of Botany, College of Agriculture, Dapoli, Dist. Ratnagiri, Maharashtra state during the kharif and rabi2017-18 and 2018-19 seasons, to study the "Effect of seasons and plant spacings on quality parameters of groundnut (Arachis hypogaea L.) genotypes". The experiment was laid out in split plot design replicated three times. The main plot treatment consists of two seasons (kharif and rabi); however, sub plot treatments consist of eleven groundnut genotypes. The sub- sub plot treatments consist of three plant spacings $\left(\mathrm{D}_{1}: 30\right.$ x $20 \mathrm{~cm}, \mathrm{D}_{2}: 30$ x $15 \mathrm{~cm}$ and $\mathrm{D}_{3}: 30$ x $10 \mathrm{~cm}$ ). Results showed that different treatments had significant influence on quality parameters and yield of groundnut (Arachis hypogaea L.) genotypes. The maximum pod yield was recorded in season $S_{2}(38.71 \mathrm{q} / \mathrm{ha})$. Among the genotypes $\mathrm{G}_{3}(45.41 \mathrm{q} / \mathrm{ha})$ gave highest pod yield $\mathrm{q} / \mathrm{ha}$ which was significantly more than the rest of genotypes. Closer spacing of $30 \times 10 \mathrm{~cm}$ is the best spacing in terms of pod yield q/ha (38.09 q/ha) in groundnut genotypes. The quality parameters such as oil and protein content significantly highest was recorded in kharif seasons $(48.61 \%)$ and $(22.80 \%)$ during both years. Significantly maximum oil content was recorded in genotype $\mathrm{G}_{10}(50.39 \%)$ and maximum protein content was recorded in $\mathrm{G}_{6}(23.30 \%)$. The crop sown with $30 \times 20 \mathrm{~cm}$ spacing recorded highest protein (22.84\%) and oil content $(48.77 \%)$.

\section{Introduction}

Groundnut is one of the world's most popular crops cultivated in tropical and sub-tropical regions. Because of its high protein, oil, fatty acid, carbohydrates, vitamins and minerals contents, groundnut has high commercial and nutritional value. It contains $45-55 \%$ oil, 20 $25 \%$ protein, $16-18 \%$ carbohydrate and $5 \%$ minerals (Gulluoglu, 2011; Gulluoglu, et al., 2016a). Groundnut (Arachis hypogea L.) the king of oilseed crops plays a vital role in the economy of national edible oil.

Groundnut is one of the most important oil and protein producing crops in the world. About two-thirds of total peanut production is crushed for oil and the remaining one-third is used in confectionery products in the world (Dwivedi et al., 1993). Quality of groundnut 
seed oil is influenced by temperature and moisture. Yield of any crop is a complex phenomenon, a function of genetic factor as influenced by climate and management. The crop must be given proper management so that better growth can take place. Amongst the management practices, spacing is the most important one for determining yield. It is important to accommodate the most appropriate number of plants per unit area of land to obtain better yield. Among the various factors that influence the yield of peanut, plantation with proper spacing is very important.

Planting density is one of the main factors that play an important role on growth, yield and quality of peanut too (Awal, and Aktar, 2015). Plant populations, cultivar, cultural practice and other environmental factors, interact with each other determine yield and quality. The purpose of this study was to determined, how quality parameters of groundnut are affected by seasons and plant spacings with different genotypes.

\section{Materials and Methods}

\section{Experimental site}

An experiment was conducted in the Education and Research Farm of the Department of Botany, College of Agriculture, Dapoli, during the kharif and rabi 2017-18 and 2018-19 seasons. Geographically the site is situated in the subtropical region on the $17045^{\prime}$ North latitude and 730 12' East longitude having elevation of 250 meters above the mean sea level. The average annual precipitation is $3500-4000$ $\mathrm{mm}$, which is generally received from June to October. The metrological observations during the period of experimentation were recorded at the metrological observation at the College of Agriculture, Dapoli.

\section{Land preparation and fertilization}

The experimental field was first opened by a tractor drawn disc plough and two ploughings were done. After five days the land was further ploughed with a power tiller followed by laddering to get a good tilth. Weeds and stubbles were removed from the field prior to planting of seed. A uniform dose of $30 \mathrm{~kg} \mathrm{~N}$, $40 \mathrm{~kg}$ P2O5 and $50 \mathrm{~kg} \mathrm{~K} 2 \mathrm{O}$ ha-1 was applied through urea, single super phosphate and muriate of potash, respectively to all the plots. The experimental soil is lateritic type having acidic in reaction and medium in available macronutrients. The entire dose of phosphorous, potassium and $20 \mathrm{~kg} \mathrm{~N}$ ha-1 were applied as basal at the time of sowing and remaining $10 \mathrm{~kg} \mathrm{~N}$ ha-1 was applied as top dressing at $30 \mathrm{DAS}$. Gypsum was applied @ $500 \mathrm{~kg}$ ha-1 at 40 days after sowing.

\section{Experimental treatment, design and crop culture}

The main plot treatment consists of two season's viz., S1: Kharif and S2: Rabi. However, sub plot treatments consist of eleven groundnut genotypes viz., G1: RTNG14, G2: RTNG- 53, G3: RTNG- 27, G4: RHRG- 1308, G5: RHRG- 1435, G6: KDG160, G7: KDG-187, G8: TKG- Bold, G9: JL1232, G10: Konkan Bhuratna and G11: KonkanGaurav. The sub- sub plot treatments consist of three plant spacings viz., D1: $30 \mathrm{x}$ $20 \mathrm{~cm}, \mathrm{D} 2: 30 \mathrm{x} 15 \mathrm{~cm}$ and D3: $30 \mathrm{x} 10 \mathrm{~cm}$. The experiment was laid out in a split plot design. The seeds were sown in line manually by hand. Three seeds were sown in a place and after seedling emergence one healthy plantlet was kept for continuation of crop growth. Spraying of Monocrotophos @ $1.6 \mathrm{ml}$ liter-1 of water for the control of leafminer at 28 DAS and Chlorpyriphos @ 3.0 mllitre-1of water for the control of Spodoptera at 47 DAS was carried out. Weeding was done as and when necessary. Statistical analysis of the 
data obtained during the course of investigation was carried out by using standard statistical analysis method of analysis of variance and correlation coefficient, as described by Panse and Sukhatme (1985).

\section{Results and Discussion}

\section{Pod yield q/ha}

The influence of different treatments on pod yield q/ha was statistically significant (Table 1 and Fig. 1). Effect of seasons on pod yield $\mathrm{q} /$ ha was found significant, the maximum pod yield was recorded in season $\mathrm{S}_{2}(38.71 \mathrm{q} / \mathrm{ha})$. The yield of Rabi grown groundnut is significantly highest than Kharif grown mainly because of maximum temperature and bright sunshine hours during the flowering phase. Due to longer duration and more sunshine hours, the dry season crop produced more pod yield and total dry matter than the wet season crop (Singh and Joshi, 1993).Vijayakumar et al., (2003) observed that groundnut varieties gives higher yield ( $\mathrm{q}$ $\mathrm{ha}^{-1}$ ) in rabi/summer grown groundnut compared to kharif grown.

The increased in the yield of $\mathrm{G}_{3}$ (RTNG-27) was mainly attributed more number of pods, pod weight compared to remaining genotypes. Hatwar and Mahajan (1992), Chaniyara (2001) also observed improvement in yield attributes due to genotype having ability to produce the more number of pods, shelling percentage and dry yield. Similarly Bhosale and Andhale (1981), Jagtap and Deokar (1983), Attarde et al., (2001) also observed differences in yield attributing character under different genotypes of groundnut. Among the genotypes $\mathrm{G}_{3}(45.41 \mathrm{q} / \mathrm{ha})$ gave highest pod yield $\mathrm{q} / \mathrm{ha}$ which was significantly more than the rest of genotypes. However, $\mathrm{G}_{1}(43.70$ $\mathrm{q} / \mathrm{ha}$ ) at par with each other. The lowest pod yield was recorded in $\mathrm{G}_{11}(23.44 \mathrm{q} / \mathrm{ha})$ in comparison to other genotypes. The differences in number of pods among the genotypes could be attributed to genotypic differences and their response to adverse environmental effects.

The effect of spacing on the pod yield $\mathrm{q} / \mathrm{ha}$ was found significant (Table 1 and Fig. 1) where the crop grown with 30 x $10 \mathrm{~cm}(38.09$ $\mathrm{q} / \mathrm{ha}$ ) spacing produced the highest yield and lowest yield was obtained from the $30 \times 20$ $\mathrm{cm}(28.78 \mathrm{q} / \mathrm{ha})$ spacing. The interaction between Seasons and Genotypes (SXG), seasons and spacings (SXD) as well as genotypes and spacings (GXD) was found significant. This result is in agreement with the results of many researchers (Tavora et al., 2002; Jordan et al., 2005; Gopal et al., 2007, Ramesh and Sambasiva Reddy (2007), and Howlader et al., (2009) who reported that the pod yield of groundnut were significantly greater with closer spacing might be due to the reason that the increased plant population.

\section{Interaction effects of Seasons and Genotypes}

The interaction (Table 2) revealed that, treatments S2G3 (51.02 q/ha) shows highest pod yield which was at par with S2G1 (49.42 $\mathrm{q} / \mathrm{ha}$ ) over other treatments. Among the rest of treatments combinations, S2G1 (49.42 q/ha) recorded higher pod yield followed by S2G2 (47.16 q/ha which was statistically at par with each other. The lowest pod yield was recorded in S1G11 treatments combinations (19.84 q/ha).

\section{Interaction effects of Seasons and Spacings}

Result in (table 3) indicated that, treatments S2D3 (44.75 q/ha) recorded significantly highest pod yield over other treatments combinations. On the other hand, the lowest pod yield was found in S1D1 (25.64q/ha). 
Interaction effects of Genotypes and Spacings

significantly highest pod yield which was at par with G1D3 (50.26 q/ha) over other treatments. Whereas, the lowest pod yield was

The interaction (Table 4) revealed that, recorded in G11D1 (20.72q/ha). treatments G3D3 (52.32 q/ha) recorded

Table.1 Influence of seasons and spacings on yield and quality parameters of different groundnut genotypes (pooled)

\begin{tabular}{|c|c|c|c|}
\hline Treatments & $\begin{array}{l}\text { Pod } \\
\text { yield }\left(q / h^{-1}\right)\end{array}$ & $\begin{array}{c}\text { Protein } \\
(\%)\end{array}$ & Oil (\%) \\
\hline \multicolumn{4}{|l|}{ Seasons } \\
\hline S1-Kharif & 29.01 & 22.80 & 48.61 \\
\hline S2-Rabi & 38.71 & 22.58 & 48.34 \\
\hline S.E \pm & 0.190 & 0.007 & 0.045 \\
\hline C.D at $5 \%$ & 1.157 & 0.040 & 0.272 \\
\hline \multicolumn{4}{|l|}{ Genotypes } \\
\hline G1-RTNG 14 & 43.70 & 22.96 & 48.14 \\
\hline G2-RTNG 53 & 41.40 & 22.14 & 50.23 \\
\hline G3-RTNG 27 & 45.41 & 22.21 & 49.02 \\
\hline G4 -RHRG 1308 & 33.00 & 23.28 & 48.27 \\
\hline G5 -RHRG 1435 & 27.21 & 22.36 & 47.57 \\
\hline G6-KDG 160 & 31.20 & 23.30 & 48.27 \\
\hline G7 -KDG 187 & 24.84 & 23.04 & 47.40 \\
\hline G8-TKG Bold & 34.70 & 22.12 & 48.65 \\
\hline G9 -JL 1232 & 29.65 & 22.90 & 46.35 \\
\hline $\begin{array}{l}\text { G10 - } \\
\text { KonkanBhuratna }\end{array}$ & 37.90 & 23.17 & 50.39 \\
\hline $\begin{array}{l}\text { G11 - } \\
\text { KonkanGaurav }\end{array}$ & 23.44 & 22.12 & 48.94 \\
\hline S.E \pm & 0.645 & 0.083 & 0.089 \\
\hline C.D at $5 \%$ & 1.843 & 0.239 & 0.253 \\
\hline \multicolumn{4}{|l|}{ Spacings } \\
\hline D1 $-30 \times 20 \mathrm{~cm}$ & 28.78 & 22.84 & 48.77 \\
\hline D2-30X15cm & 34.70 & 22.71 & 48.46 \\
\hline D3 -30X10 cm & 38.09 & 22.53 & 48.20 \\
\hline S.E \pm & 0.278 & 0.036 & $\mathbf{0 . 0 3 3}$ \\
\hline C.D at $5 \%$ & 0.780 & 0.102 & 0.093 \\
\hline \multicolumn{4}{|l|}{ Interaction effects } \\
\hline S X G & SIG & NS & NS \\
\hline S X D & SIG & NS & NS \\
\hline G X D & SIG & NS & NS \\
\hline S X G X D & NS & NS & NS \\
\hline General Mean & 33.86 & 22.69 & 48.48 \\
\hline
\end{tabular}


Table. 2 Interaction effect of seasons and genotypes on pod yield $\left(\mathrm{q} / \mathrm{ha}^{-1}\right)$ at harvest

\begin{tabular}{|c|c|c|c|c|c|c|c|c|c|c|c|}
\hline \multirow{2}{*}{ Seasons } & \multicolumn{10}{|c|}{ Genotypes } \\
\hline S1 & G1 & G2 & G3 & G4 & G5 & G6 & G7 & G8 & G9 & G10 & G11 \\
\hline S2 & 37.97 & 35.65 & 39.80 & 28.42 & 22.37 & 26.20 & 20.98 & 29.73 & 25.09 & 33.01 & $\mathbf{1 9 . 8 4}$ \\
\hline SEm \pm & 49.42 & 47.16 & 51.02 & 37.58 & 32.05 & 36.20 & 28.71 & 39.66 & 34.22 & 42.78 & $\mathbf{2 7 . 0 3}$ \\
\hline
\end{tabular}

Table.3 Interaction effect of seasons and spacings on pod yield (q/ha-1) at harvest

\begin{tabular}{|c|c|c|c|}
\hline \multirow{2}{*}{ Seasons } & \multicolumn{3}{|c|}{ Spacings } \\
\cline { 2 - 4 } & D1 & At harvest & D3 \\
\hline S1 & 25.64 & D2 & $\mathbf{3 1 . 4 4}$ \\
\hline S2 & 31.92 & 39.94 & $\mathbf{4 4 . 7 5}$ \\
\hline SEm \pm & $\mathbf{0 . 3 9 3}$ & C.D. at 5\% & $\mathbf{1 . 1 0 4}$ \\
\hline
\end{tabular}

Table.4 Interaction effect of genotypes and spacing on pod yield (q/ha-1) at harvest

\begin{tabular}{|c|c|c|c|}
\hline \multirow{2}{*}{ Genotypes } & \multicolumn{3}{|c|}{ Spacings } \\
\hline & D1 & D2 & D3 \\
\hline G1 & 36.43 & 44.40 & 50.26 \\
\hline G2 & 34.63 & 42.01 & 47.57 \\
\hline G3 & 37.92 & 45.99 & 52.32 \\
\hline G4 & 28.02 & 34.07 & 36.92 \\
\hline G5 & 23.99 & 28.18 & 29.45 \\
\hline G6 & 26.38 & 32.19 & 35.02 \\
\hline G7 & 21.78 & 25.57 & 27.19 \\
\hline G8 & 29.44 & 35.67 & 38.99 \\
\hline G9 & 25.73 & 30.69 & 32.54 \\
\hline G10 & 31.54 & 38.86 & 43.29 \\
\hline G11 & 20.72 & 24.11 & 25.47 \\
\hline S.E \pm & \multicolumn{3}{|c|}{0.921} \\
\hline C.D at $5 \%$ & \multicolumn{3}{|c|}{2.588} \\
\hline
\end{tabular}

Fig.1 Influence of seasons and spacings on yield of different groundnut genotypes (pooled)

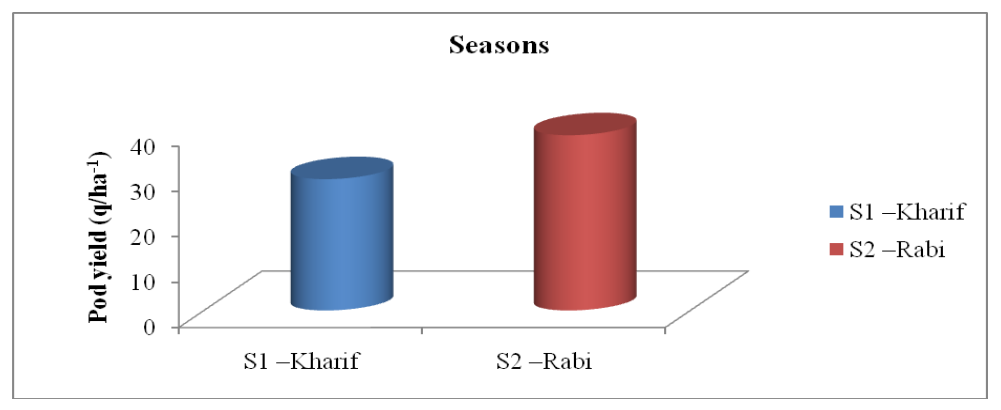



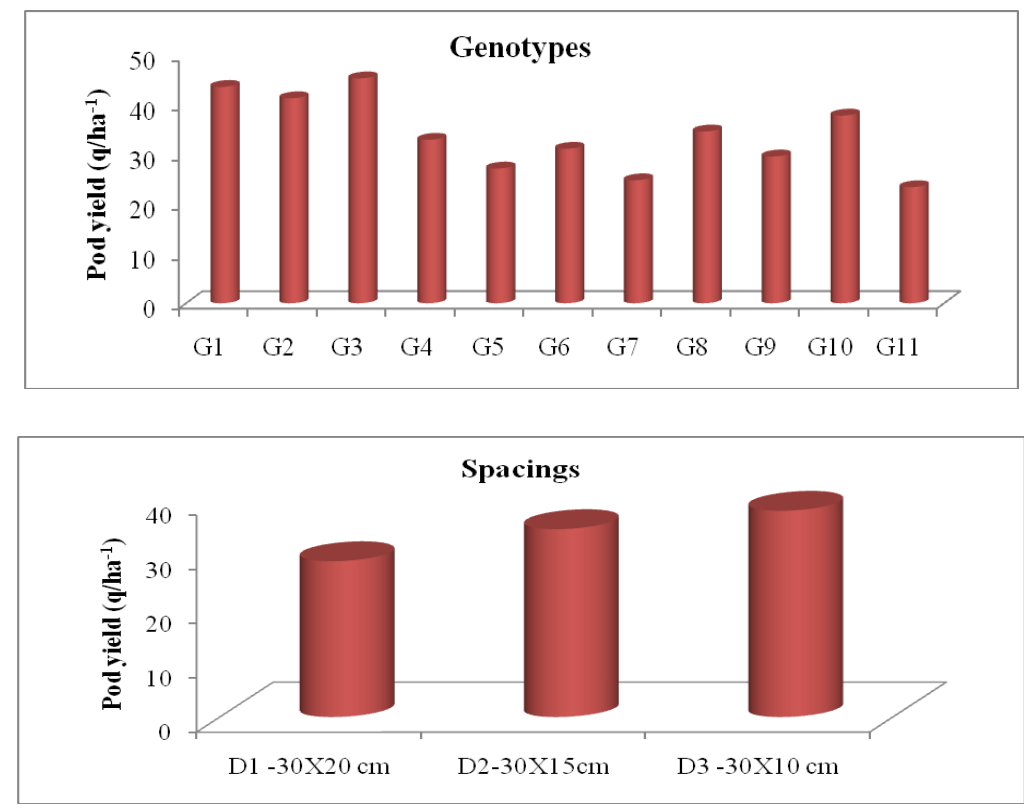

Fig.2 Influence of seasons and spacings on quality parameters of different groundnut genotypes (pooled)
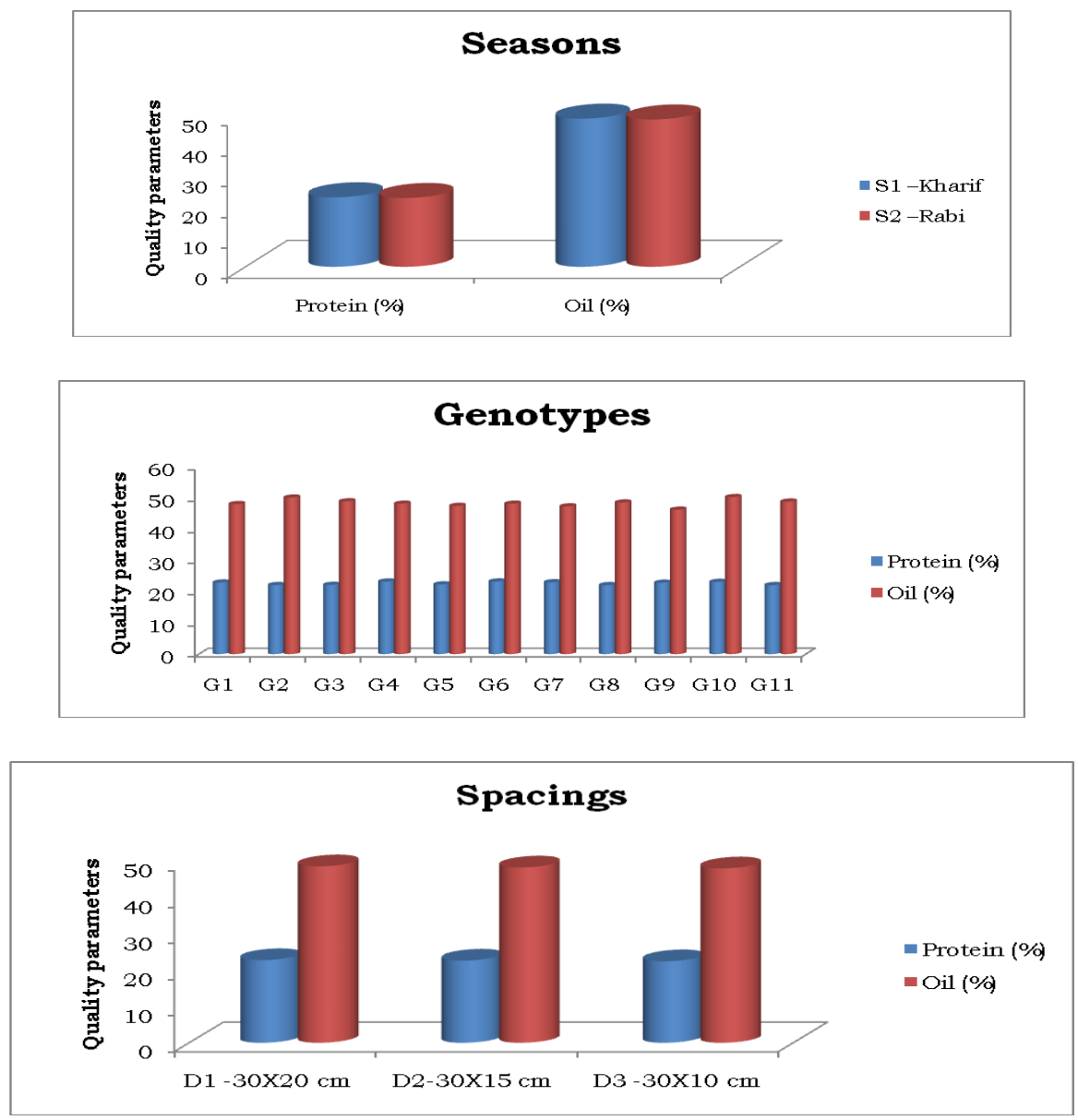


\section{Protein content $(\%)$}

Peanut are a good source of protein. The protein content ranges from $22-30 \%$ of its total calories, making peanuts are great source of plant-based protein. The most abundant proteins in peanut area rachin and conarchin. Effect of season on protein content was found significant, highest protein content $(22.80 \%)$ was recorded in kharif seasons (S1)(Table 1 Fig. 2). The highest protein content was recorded in seasons $S_{1}$ (kharif) than $S_{2}$ (rabi) season. Hence, for getting higher protein, the kharif groundnut is preferred may be due to effect of temperature. The temperature has been found to play an important in determining the protein contents and high temperature decrease the protein content. These results are in accordance with the findings of (Werner, 1995).The protein content in groundnut kernels varies depending on cultivar, location, season, seed maturity and agronomic practices. Average protein content is higher than that of eggs, dairy products, meat and fish and the digestibility of groundnut protein is very high (Singh and Singh, 1991).

Out of 11 genotypes tested, significantly maximum protein content was recorded in $\mathrm{G}_{6}$ (23.30\%) (KDG-160) which was at par with $\mathrm{G}_{4}(23.28 \%)$ (RHRG-1308) and $\mathrm{G}_{10}(23.17 \%)$ (Konkan Bhuratna) over other genotypes. Whereas, the lowest protein content was recorded in $\mathrm{G}_{11}(22.12 \%)$ (Konkan-Gaurav) and $\mathrm{G}_{8}(22.12 \%)$ (TKG- Bold) over rest of the genotypes. Genotypic difference for protein content was also reported by Borkar and Dharanguttikar (2014).

Crop grown with spacings $\mathrm{D}_{1}(30 \mathrm{X} 20$ $\mathrm{cm})(22.84 \%)$ exhibited significantly higher protein content over spacing $\mathrm{D}_{3}(30 \times 10$ $\mathrm{cm})(22.53 \%)$. Data indicated highest protein was obtained at wider spacing these results are in conformity with those of El-far and
Ramadan (2000) and Ramesh and Sabale (2001).

\section{Oil content (\%)}

Groundnut seed contains approximately 50\% oil. The nutritional and storage qualities of peanut are determined by its fatty acids composition. According to Andersen and Gorbet (2002) peanut oil contains both saturated and unsaturated fatty acids. The oil content was influenced significantly within seasons. Significantly highest oil content (48.61\%)was recorded in kharif seasons (S1) (Table 1 and Fig. 2). In the present investigation, significantly highest oil content was recorded in seasons S1 (kharif) one might be due to abiotic factors such as rainfall, and other environmental parameters of a native season of seeds, which gave variation in seed quality parameters such as germination, seedling vigour index and seed weight. Similar difference in oil content due to seasons was revealed by Padma et al., (1987), Bagewadi and Pundaleek (2000) and Limbani (2006).

Significant difference was observed among all genotypes for oil content, significantly maximum oil content was recorded in $\mathrm{G}_{10}$ (Konkan Bhuratna) $(50.39 \%)$ which was at par with $\mathrm{G}_{2}$ (RTNG-53)(50.23\%) over other genotypes. The lowest oil content was recorded in $\mathrm{G}_{9} \quad(\mathrm{JL}-1232)(46.35 \%)$ in comparison to other genotypes was mainly governed by the genetic makeup of the genotype. Genotypic variation for oil content was also reported by Srinivas Kumar (1992), Appavu (2004), Howlander et al., (2009), Soumya (2011) and Jeyaramraja and Fantahun (2014).

Groundnut sown at widely spaced plant spacings of $(30 \times 20 \mathrm{~cm})$ had significantly highest growth and quality characters over rest of plant spacings. The maximum and 
minimum oil content was obtained with the plant spacingsofD $1(30$ X $20 \mathrm{~cm})(48.77 \%)$ and $\mathrm{D}_{3}(30 \mathrm{X} 10 \mathrm{~cm})(48.20 \%)$ respectively. And results showed that the higher plant density gave lowest seed oil percentage. While over plant density gave the highest seed oil percentage. These results are in conformity with those of Patel and Patel (1995) and Subrahmaniyan et al., (2010), Bhagavatha (2016) and Dheya and Ahmad (2019).

In conclusion the rabi groundnut gives higher yield than that of kharif season mainly because of higher photosynthetic rate, stomatal conductance, water use efficiency, net assimilation rate and leaf area index. Out of all the plant density studied, plant spacing $30 \times 10 \mathrm{~cm}$ performed best with respect to seed yield (q/ha). Irrespective of genotypes and spacings the kharif groundnut gives higher protein and oil content than that of rabi season. The plant spacing 30 X $20 \mathrm{~cm}$ performed best with respect to both quality characters. Protein and oil content was decreased when the plant density was increased. The highest protein and oil content was obtained from $30 \times 20 \mathrm{~cm}$ and the lowest from $30 \times 10 \mathrm{~cm}$ planting density according to a two year average (pooled).

\section{Acknowledgment}

The authors are thankful to the Associate Dean, COA, Dapoli for sparing the experimental site and also grateful to the Director of Research, Dr. BSKKV, Dapoli, for providing genotypes of groundnut.

\section{References}

Andersen, P.C., andGorbet, D.W. (2002). Influence of year and planting date on fatty acid chemistry of high oleic acid and normal peanut genotypes. Journal of Agricultural and Food Chemistry,
50:1298-1305.

Appavu, K. (2004). Influence of different varieties and nitrogen levels on yield and yield atiributes of sesamum. Agricultural Science Digest, 24(1): 1-4.

Attarde, D.R., Shinde, Y.M., Suryawanshi, R.T., Narkheet, T.N., and Wadile, S.C. (2001).Effect of seed rate and row row spacing on the yield of groundnut variety GG-33. J. Maharashtra Agric. Univ. 23(3):243-244.

Awal, M. A., and Aktar, L. (2015).Effect of row spacing on the growth and yield of peanut (Arachishypogaea L.) stands.International Journal of Agriculture, Forestry and Fisheries, 3(1): 7.

Bagewadi, C., andPundaleek, (2000).Studies on nutrition and seasons on seed yield and quality in groundnut varieties JL24. M.Sc. Thesis submitted to University of Agricultural Sciences, Bangalore.

BhagavathaPriya T., Subramanyam D., Sumathi V. and Naidu M. V. S. (2016).Growth characters and yield of early kharif groundnut as influenced by varieties and plant populations.IOSR Journal of Agriculture and Veterinary Science, 9(5):81-83.

Bhosale, R.T. and Andhale, R.K. (1981).Studies on yield performance of some high yield varieties of groundnut under heavy rainfall condition. J. MAU, 6(2):156-157.

Borkar, V. H., and Dharanguttikar, V. M. (2014).Evaluation of groundnut (ArachishypogaeaL.) genotypes for physiological traits.International Journal of Scientific and Research, 4(1): 1-8.

Chaniyara, N.J., Solanki, R. and Bhale, V.B. (2001). Response of groundnut to spacing and plant population, Legume Res. 24(4):252-255.

Dheya, P. Y. and Ahmad, H. (2019).Effect of 
genotype and plant density on growth characteristics and yield of peanut (Archishypogaea L.) in central region of Iraq.Agricultural Research \& Technology: Open Access Journal, 19(3): 101-106.

Dwivedi, S.L, Reddy, D.V.R., Nigam, S.N., RangaRao, G.V., Wightman, J.A., Amin, P.W., Nagabhushanam, G.V.S., Reddy, A.S., Scholberg, and E., Ramraj, V.M. (1993). Registration of ICGV 86031 peanut germplasm. Crop Science, 33:220.

El-Far, I. A., and Ramadan, B. R. (2000). Response of yield, yield components and seed quality of peanut to plant density and PK fertilization in sandy calcareous soil. IOSR Journal of Agriculture and Veterinary Science. 7(5): 63-70.

Gopal, K., Muniyappa, V., Jagadesgwar, R. (2007).Management of peanut bud necrosis disease in groundnut through manupulation of date of sowing and plant population. Journal of Plant Disease Science 2 (2): 157-161.

Gulluoglu, L. (2011). Effects of Regulator Applications on Pod Yield and Some Agronomic Characters of Peanut in Mediterranean Region. TurkJournalField Crops.16 (2):210214.

Gulluoglu, L., H. Bakal, B. Onat, C. Kurt, and H. Arioglu.(2016a). The Effect of Harvesting Dates on Yield and Some Agronomic and Quality Characteristics of Peanut Grown in Mediterranean Region (Turkey) Turk J Field Crops.21 (2):224-232.

Hatwar, K.G. and Mahajan, M.S. (1992).Response of groundnut varieties to plant densities and phosphorous levels.PKV. Res J.16 (2):273-274.

Howlander, S.H., Bashar, H. M. K., Islam, M. S., Mamun, M. H. and Jahan, S.M. H. (2009). Effect of plant spacings on the yield and yield attributes of groundnut. International Journal on Sustainable Crop Production, 4(1): 41-44.

Jagtap, D.P. and Deokar, (1983).A new semi spleating groundnut variety for summer culvationsutiable for western Maharashtra seed and farms.9 (11):2123.

Jeyaramraja, P. R., and Fantahun, W. (2014).Characterization of yield components in certain groundnut (ArachishypogaeaL.) varieties of Ethiopia.Journal of Experimental Biology and Agricultural Sciences, 2(6): 592-596.

Jordan, D. L., Beam, J. B., Johnson, P. D. and Speears, J. F. (2005).Peanut response to prohexadione calcium in three seeding rate-row pattern planting systems. Madison, USA. Agronomy Journal, 93 (1): 232- 236.

Limbani A. K. (2006). Effect of provenance, season and invigouration treatments on seed yield and quality of groundnut [ArachishypogaeaL.]M.Sc. Thesis submitted to the University of Agricultural Sciences, Dharwad.

Padma, V. MadhusudanRao, D.V. and SubbaRao, I, V., (1987).Response of groundnut cultivars to time of sowing in different seasons. Journal of Oilseeds Research, 8: 275-279.

Panse, V. G. and Sukhatme, P. V. (1985).Statistical Methods for Agricultural Workers.Indian Council of Agricultural Research, New Delhi.167174.

Patel, J. B., and Patel, I. S. (1995).Effect of irrigation, interrow spacing, and seed rate on quality and economics of summer groundnut, InternationalArachis Newsletter. 15: 85-86.

Ramesh, G., and Reddy, A. S. S. (2007). Production potential of rabi groundnut, Arachis hypogaea L. in relation to plant 
density and genotypes. Journal of Oilseeds Research, 24(2): 322.

Ramesh, N., and Sabale, R. N. (2001).Effect of phosphate fertilization, phosphatesolubilizer and plant population on yield and quality of summer groundnut (Arachishypogaea).Indian Journal of Agronomy, 46(1):156-161.

Singh, A. L., and Joshi, Y. C., (1993). Comparative studies on chlorophyll content, growth, $\mathrm{N}$ uptake and yield of groundnut varieties of different habit groups. Oleagineux 48: 27-34.

Singh, B., Singh, U., (1991). Peanut as a source of human foods.Plant Foods Hum.Nutr.41: 165- 177.

Soumya, B., (2011). Standardization Of Seed Rate For Promising Groundnut Varieties Under Rainfed Conditions Of Southern Telangana Zone, Andhra Pradesh. M.Sc. thesis submitted to the Acharya N.G. Ranga Agricultural University.

Srinivas Kumar, A. (1992). Response of groundnut (Arachishypogaea $\mathrm{L}$.) varieties to varying plant densities.
M.Sc. (Ag) thesis submitted to the Andhra Pradesh Agricultural University, Rajendranagar, Hyderabad.

Subrahmaniyan, K., Kalaiselvan, P., Balasubramanian, T. N. and Zhou, W. (2010). Groundnut (Arachishypogaea) response to herbicides, plant geometry and plastic mulches under irrigated condition. Indian Journal of Agricultural Sciences, 80(1), 89-91.

Tavora, FJAF, Henriques-Neto D, Silva, F.P and Melo F.I.O. (2002). Peanut response to plant densities and planting pattern: light interception, growth analysis and yield. Revista- CienciaAgronomica, 33 (2): 5-12.

Vijayakumar, S., Gururaj, S. and Somasekhar, (2003).Promising varieties of groundnut for north eastern dry zone of Karnataka. Nation.Workshop on Seed Tech., 60-62.

Werner, S., (1995).Nutrional values in crop and plants. Publication faser and faser, 24, Rusel Square, London, 92.

\section{How to cite this article:}

Dhanashri Gawas, A. V. Mane, Tejas Kanase, M. M. Burondkar and Kasture, M. C. 2020. Effect of Seasons and Plant Spacings on Yield and Quality Parameters of Various Groundnut (Arachis hypogaea L.) Genotypes. Int.J.Curr.Microbiol.App.Sci. 9(10): 2676-2685. doi: https://doi.org/10.20546/ijcmas.2020.910.323 